\title{
Identification of glaciers with surge characteristics on the Tibetan Plateau
}

\author{
ZHANG WENJING \\ Lanzhou Institute of Glaciology and Geocryology, Academia Sinica, Lanzhou 730000, China
}

\begin{abstract}
Investigations of Zelunglung and Midui Glaciers in southeast Tibet, China, indicate that they have some characteristics of surge-type glaciers. There have been two extraordinary movements of Zelunglung Glacier, one in 1950 and one in 1968. A collapse of the terminus area took place in 1984. Midui Glacier experienced extraordinary movements about 55 years ago and also in 1988. During these events, the glacier termini reached moraines formed during neoglaciation and the Little Ice Age. The advances of the two glaciers are not related to climate variation. The glaciers caused serious disasters with loss of life and property, and disruption of transportation corridors.
\end{abstract}

\section{INTRODUCTION}

Several glaciers with surge characteristics have been found in the Tibet Plateau since the 1970s (Zhang, 1985, 1987). The most detailed data are available for Zelunglung Glacier on the west slope of Namjagbarwa Peak (7782 $\mathrm{m}$ a.s.1.) and Midui Glacier in eastern Bomi County (Fig. 1). Zelunglung Glacier experienced dramatic changes in 1950, 1968 and 1984. Midui Glacier appears to surge about every 50 to 60 years.
The identification of rapid glacier changes in this area of Tibet is important for assessment of glaciological hazards. This paper provides historical information about Zelunglung and Midui Glaciers. This information can help in the assessment of future hazards resulting from internal dynamical processes in these glaciers, and having no causal relation with specific climate or weather events (Post, 1960).

World-wide surge behaviour of glaciers is concentrated in certain regions and almost absent in others (e.g.

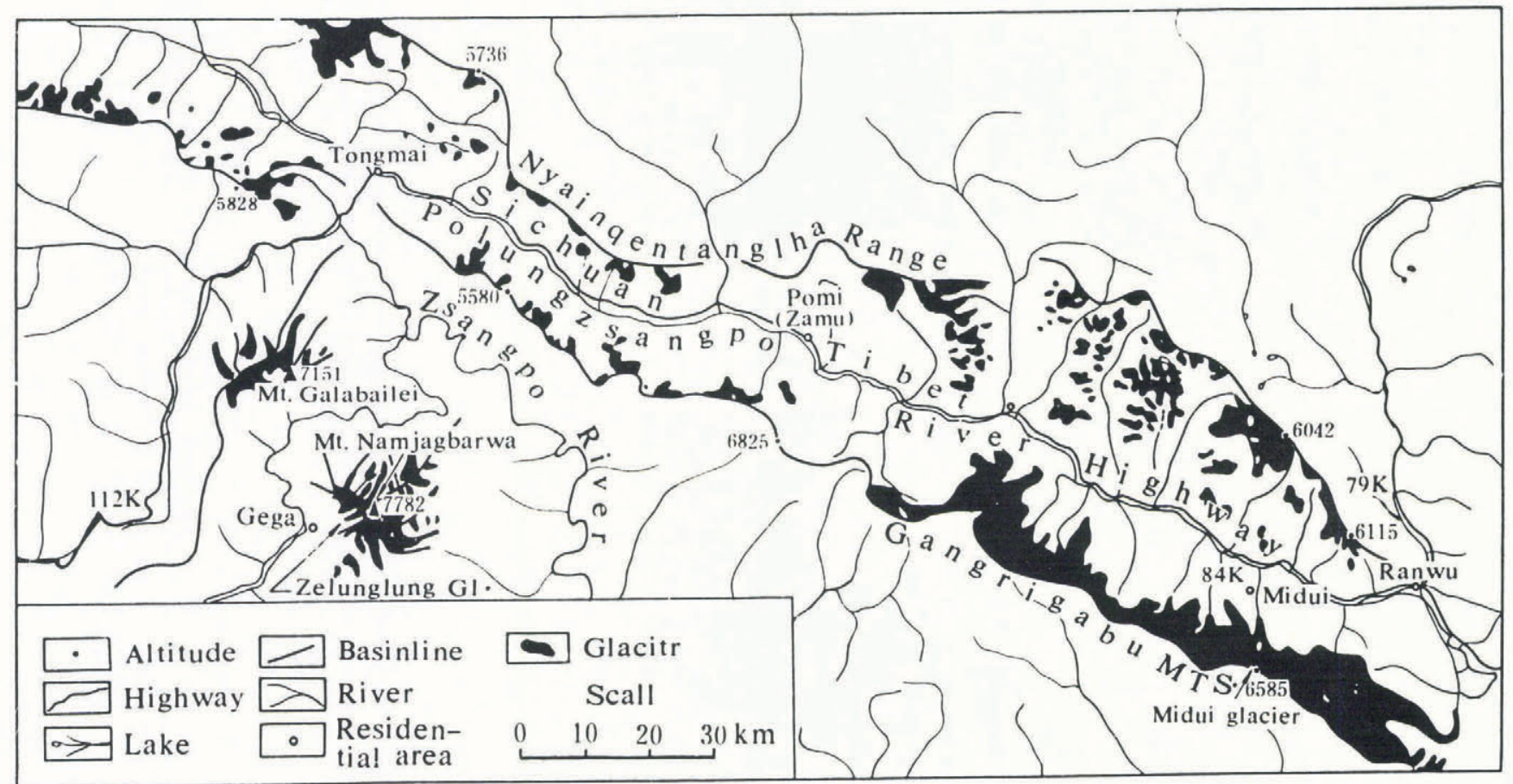

Fig. 1. Locations of glaciers in southeastern Tibet. 


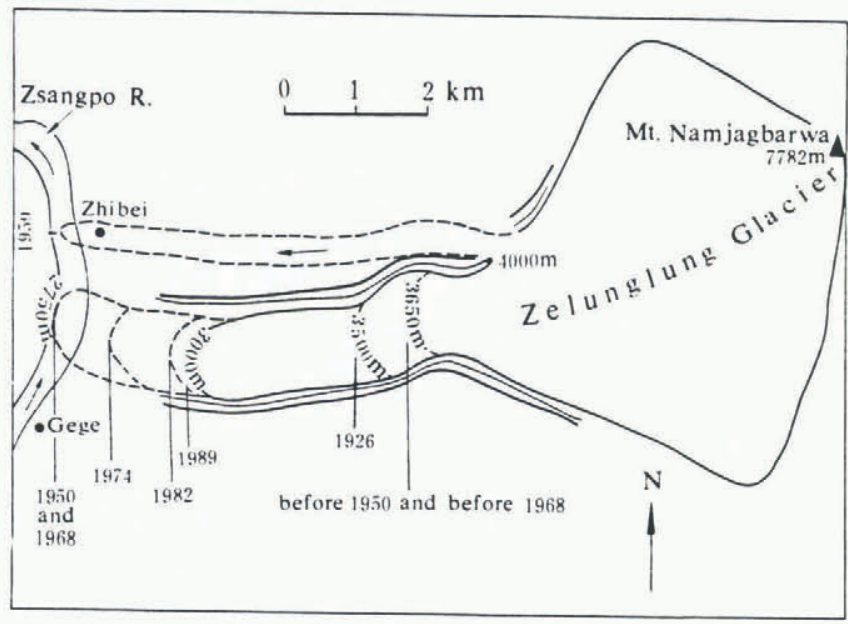

Fig. 2. Sketch map showing the changes of the terminus of Zelunglung Glacier from the 1920s to 1989. Contours show approximate elevation of the ice surface in an extended state.

Post, 1960). This geographical distribution must be related to the mechanism of surge behaviour and must contain information about the cause of surges, but the explanation is as yet unknown. This paper provides new information about the geographical distribution of glaciers with surge characteristics.

Scientific investigation of the area of the Tibetan Plateau to determine the presence of surge behaviour of glaciers first occurred in 1982 to 1984, during an expedition to Mount Namjagbarwa. Preliminary results were published by Zhang (1985, 1987). Additional information was obtained in 1990 during an assessment of glacier hazards on the Sichuan-Tibet Highway in Bomi County, Tibet. This paper synthesizes information about the history, glacier geomorphology, and physical features of the glaciers.

\section{GHARACTERISTICS OF ZELUNGLUNG GLACIER}

Zelunglung Glacier (Fig. 2) lies in Zelunglung valley on the west slope of Mount Namjagbarwa $\left(29^{\circ} 37^{\prime} 9^{\prime \prime} \mathrm{N}\right.$, $95^{\circ} 03^{\prime} 3^{\prime \prime} \mathrm{E}, 7782 \mathrm{~m}$ a.s.l.). In September 1982, the glacier was about $10.6 \mathrm{~km}$ long with an average width of $200 \mathrm{~m}$ and an area of $17.9 \mathrm{~km}^{2}$. The glacier head is at the summit of Mount Namjagbarwa. The terminus was at $2950 \mathrm{~m}$ a.s.l. in 1982. The annual snowline is between 4500 and $4800 \mathrm{~m}$ a.s.l. The glacier front extends more than $1000 \mathrm{~m}$ below the upper forest boundary $(4100 \mathrm{~m}$ a.s.l.). It is a temperate valley glacier with abundant debris on its surface. Both ice and snow avalanches occur constantly at the head of the glacier.

\section{History of Zelunglung Glacier events}

Within the past half-century, three extraordinary phases of motion took place, approximately in the years 1950 , 1968 and 1984.

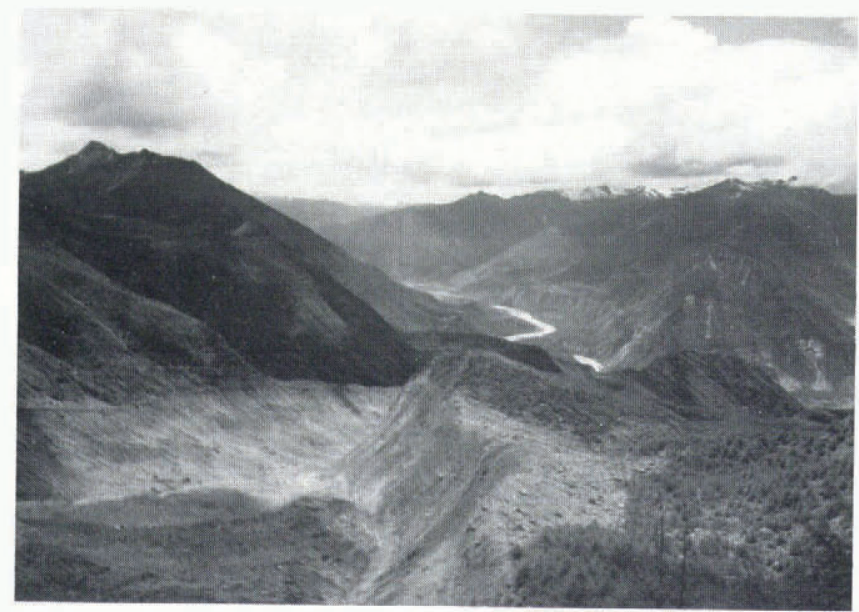

Fig. 3. Erosional scar on the lateral moraine resulting from extraordinary movement of Zelunglung Glacier in 1950.

On the evening of 15 August ( $=2$ July on the Tibetan calendar) 1950, villagers from Gege witnessed rapid sliding that was initiated abruptly on Zelunglung Glacier. Within a few hours, the glacier terminus had advanced rapidly about $4 \mathrm{~km}$ from $3650 \mathrm{~m}$ a.s.l. down to the Zsangpo River valley at about $2750 \mathrm{~m}$ a.s.l. The mean velocity of the ice displacement implied by these observations is on the order of $1 \mathrm{~km} \mathrm{~h}^{-1}$. Ice deposited by the sliding mass formed an ice dam, tens of metres high. This dam blocked the Zsangpo River temporarily.

As a result of the motion, a marginal stream on the northern side of the glacier was blocked, and glacial ice overtopped the lateral moraine at $4000 \mathrm{~m}$ a.s.l. (Fig. 3). These events resulted in an ice avalanche down the neighbouring valley. The avalanche engulfed the village of Zhibai (Fig. 2) on the evening of 15 August. Altogether, 97 villagers died in the disaster. There was only one lucky survivor. The horizontal distance covered by the avalanche was about $4.8 \mathrm{~km}$.

It is possible that these events are related to the great earthquake in Chayu that occurred on 15 August. The earthquake was of magnitude 8.5 on the Richter scale. The epicentre was about $260 \mathrm{~km}$ southeast of Mount Namjagbarwa.

The second extraordinary motion took place one afternoon in July (Tibetan calendar) 1968. At the time, the Gege villagers were busy reaping buckwheat under the hot sun. The Zsangpo River was blocked suddenly by a dam higher than $50 \mathrm{~m}$. The river remained blocked until the following day when the ice dam burst. The advancing ice crushed and buried a wooden bridge at the entrance of Zelunglung valley. The rising lake water swept away a water mill at Lukouqu stream to the south of the neighbouring valley, $50 \mathrm{~m}$ above the Zsangpo River.

The third event occurred about 3 o'clock in the morning of 13 April 1984. A huge mass of ice broke loose from Zelunglung Glacier at $3700 \mathrm{~m}$ a.s.l. The sliding ice was accompanied by loud roaring and cracking sounds. 

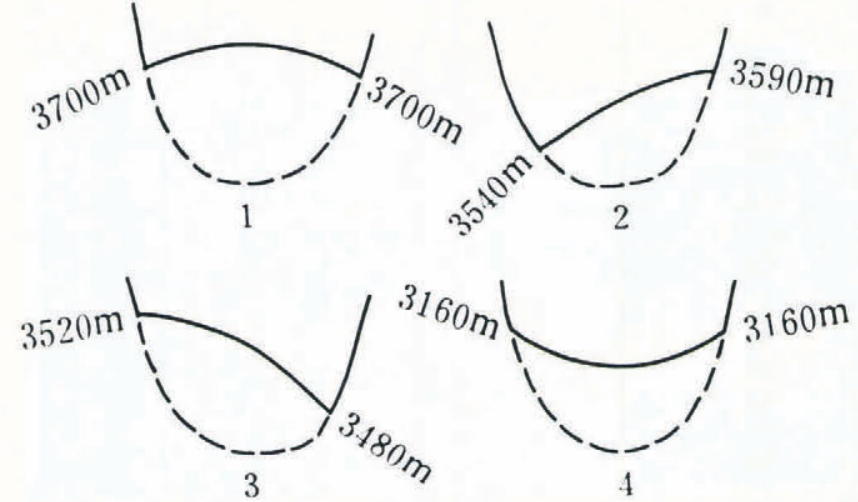

Fig. 4. Cross-sections of Zelunglung Glacier at four locations at distances of about 6.8 (1), 7.1 (2), 7.8 (3), and 10.6 (4) $\mathrm{km}$ from the glacier head. Bed profiles (dashed lines) are assumed. Surface profiles were observed in 1982 by transit.

The horizontal distance travelled by the ice averaged $150 \mathrm{~m}$, and its size was about $100 \times 20 \times 40 \mathrm{~m}^{3}$.

\section{Geomorphological features of Zelunglung Glacier events}

The 1968 activity produced some distinctive geomorphological features. Extensive crevassing, typically associated with rapid motion, was evident on the glacier. By 1982, melting had divided the ice mass into six sections. In 1989 , it was found that the fourth, fifth and sixth sections were separated from the glacier by ablation, and were buried by thick debris.

The valley has an "S" shape, and the ice flows around bends (Fig. 2). In 1982, the ice level tended to be raised along the outsides of the bends, and lowered along the insides (Fig. 4).

\section{Recent changes of Zelunglung Glacier}

In the middle of the 20th century, the glacier terminus was $3500 \mathrm{~m}$ a.s.l. with a length of $7.7 \mathrm{~km}$ (Ward, 1926). It retreated to $3650 \mathrm{~m}$ a.s.l. with a length of $7.0 \mathrm{~km}$ before the extraordinary movement in 1950. During the 1950 event, the terminus extended to the bank of the Zsangpo River, giving it a length of $11.8 \mathrm{~km}$. Immediately before the 1968 event, the terminus had retreated to its previous height of about $3650 \mathrm{~m}$. Since then, the glacier has been in retreat (Fig. 2).

\section{CHARAGTERISTICS OF MIDUI GLACIER}

Midui Glacier is located south of the Polungzsangpo River, about $120 \mathrm{~km}$ east of Zamu in Pomi County, Tibet. It is a temperate glacier on the northern slope of the eastern end of Gangrigabu mountain (Fig. 1). It has a

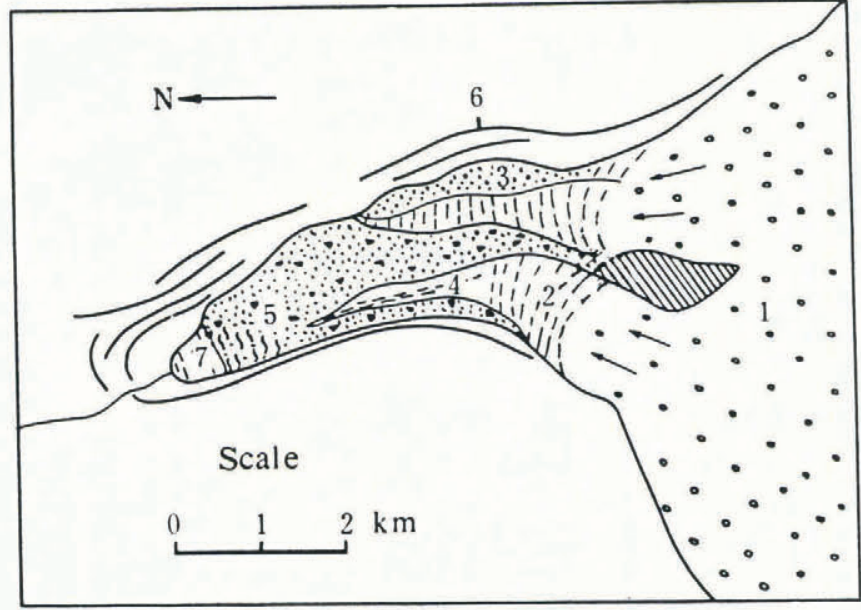

Fig. 5. Geomorphological map of Midui Glacier. 1. firm area, 2. ogive area, 3. debris-covered area, 4. area of stretched ogives, 5. area of transverse crevasses, 6. fresh moraine, 7. moraine-dammed lake. length of $10.2 \mathrm{~km}$, an area of $26.75 \mathrm{~km}^{2}$, and an average slope of $26 \%$.

The head lies at $6585 \mathrm{~m}$ a.s.l. $\left(29^{\circ} 24^{\prime} 5^{\prime \prime} \mathrm{N}, 96^{\circ} 32^{\prime} 4^{\prime \prime} \mathrm{E}\right)$. The elevation of the terminus is about $3820 \mathrm{~m}$, which is approximately $500 \mathrm{~m}$ below the tree line. The annual snowline is 4800 to $5000 \mathrm{~m}$ a.s.l. The temperature $10 \mathrm{~m}$ below the glacier surface at about $4000 \mathrm{~m}$ is between 0 and $-1^{\circ} \mathrm{C}$.

The glacier terminates in a lake formed behind a neoglacial moraine (Fig. 5). At present, the lake is $400 \mathrm{~m}$ long and $350 \mathrm{~m}$ wide.

On the 1:50000 scale topographical map, the eastern branch of Midui Glacier is called Gongza Glacier and the moraine-dammed lake is called Guangxiechuo. The accumulation area of the glacier has eastern and western branches. The two branches join at an elevation of $4100 \mathrm{~m}$ a.s.l. They maintain somewhat independent flow states and distinctive tectonic systems below the confluence. The eastern branch extends to about $3950 \mathrm{~m}$ a.s.l. to terminate without contacting the lake. This terminus advanced $4.2 \mathrm{~m}$ over a two-month observation period in summer 1990. The western branch terminates in the lake. Below their confluence, both branches are covered, to some extent, by surface debris.

\section{History of Midui Glacier surges}

At about 10 o'clock in the evening of 14 July 1988, the terminus lake of Midui Glacier suddenly began to empty through an enlarging gap in the moraine dam. A tremendous flood of unusual intensity was released. The flood gushed out from the western exit of the morainedammed lake, carrying ice blocks of various sizes. It swept away four wooden bridges and two water mills in its course. It also destroyed the woods and farmlands on both sides of the river, and nine dwellings in the village of Langgu on the bank of the middle branch of the river. 

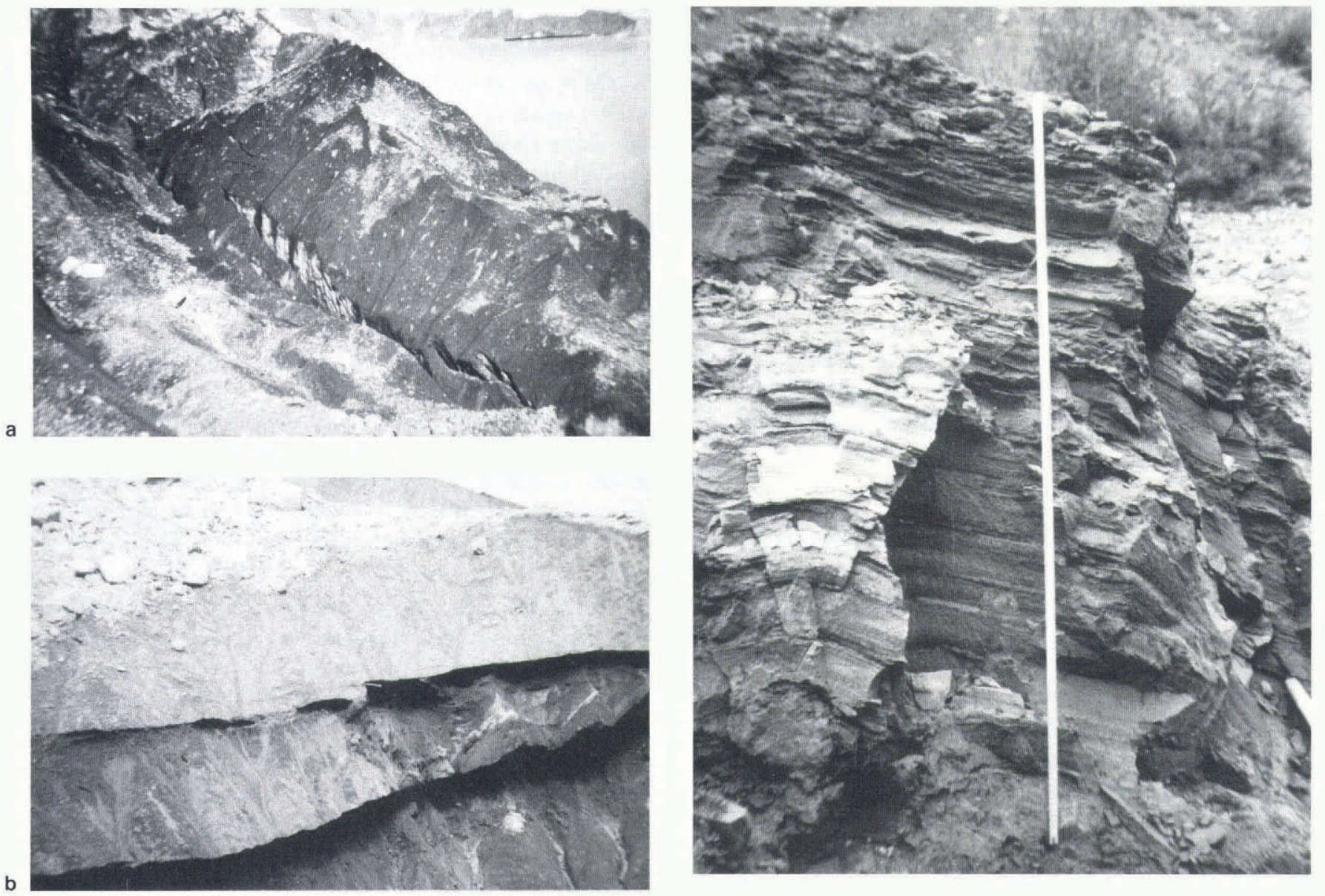

Fig. 6. (a) Transverse crevasses near the terminus of Midui Glacier. (b) Overthrusting near the terminus of Midui Glacier. A debris layer can be seen clearly between the upper and lower ice layers. (c) Sediments in the terminal lake of Midui Glacier after being exposed in 1988.

Five people died in the disaster. It took no more than 30 minutes for the flood to reach the Polungzsangpo River and raise its level. This caused flooding and destruction of about $24 \mathrm{~km}$ of the Sichuan-Tibet Highway. The instantaneous discharge was estimated to reach $833 \mathrm{~m}^{3} \mathrm{~s}^{-1}$, which is 400 times larger than the normal annual average discharge in Midui valley.

Investigations show that a rapid advance of Midui Glacier into the lake initiated the flooding. Calving of the glacier into the lake caused overflow across the moraine dam.

The primary evidence is: (a) large numbers of icebergs calved into the lake; (b) the terminus above the lake had a gentle slope before the flooding, but afterwards there was an ice cliff rising about 15 to $20 \mathrm{~m}$ above the lake; (c) in comparison with an aerial photograph taken in 1968, the ogive pattern along the western glacial stream had been extended and the terminus was cut by many transverse crevasses (Fig. 6a); (d) fresh remains of trees were found on the surface near the terminus. These fresh trees were deposited on the glacier from a hill slope farther up-valley, and were transported about $2.3 \mathrm{~km}$ to the observed location. It would take more than ten years to transport trees this distance at the normal speed of the glacier; (e) overthrust faults were pervasive in the terminus area (Fig. 6b), and glacial ice was piled on the tree-covered lateral moraines; ( $f$ ) folds and cracks were observed in the lake sediments after the lake drainage (Fig. 6c); these were probably caused by compression by the advancing ice mass; $(\mathrm{g})$ ice blocks remained on the western bank of the lake, on which there was a thick covering of fresh unvegetated moraine.

An earlier extraordinary movement of Midui Glacier appears to have taken place about 50 to 60 years ago. The following data support this conclusion.

\section{Historical evidence}

Local dwellers remember that the glacier was in a significantly advanced state 50 to 60 years ago, in comparison to the present. According to maps compiled in 1933, there was no moraine lake at the glacier terminus (Ward, 1934), indicating that the ice was in an advanced state, and that the lake resulted from glacial recession within the last half-century.

\section{Glacier deposits}

During Holocene time, there were two obvious glacial advances: one occurred during the "Xuedang" neoglaciation dated in southeastern Tibet some $2980 \pm 150$ a BP ( $\mathrm{Li}, 1986)$; the other occurred during the Little Ice Age 
about 300 years ago. Since the Little Ice Age, several minor advances have occurred, but none of them left morphological features comparable to those from the Little Ice Age. Our investigations revealed that relatively new drift was scattered over the inner side of the neoglacial and/or the Little Ice Age lateral moraines. Morphological features identified on aerial photographs taken in 1968 indicate that a large-scale glacial advance occurred sometime after the Little Ice Age.

\section{Growth rings of trees}

Two poplar trunks of 0.40 and $0.42 \mathrm{~m}$ diameter were sampled from the fresh moraine. The trees were 49 and 53 years old respectively. Trees on an island in the lake were 30 years old.

\section{Lake sediments}

Sediments exposed after the lake drained had 28 layers which are presumed to be annual. When disturbance during the lake drainage is taken into account, the age of the lake thus indicated appears consistent with the above ages of trees.

Generally, glaciers have been retreating since the Little Ice Age. However, in view of the above data, Midui Glacier was apparently in an unusually advanced state in relation to its neoglacial maximum. This advance apparently cannot be explained by climate variations since the Little Ice Age; it is most likely due to a sudden extraordinary movement similar to a surge.

From the above information, we conclude that there have been two rapid advances of Midui Glacier during the last 50 to 60 years.

\section{Description of glaciological features of Midui Glacier}

\section{Morphology of the ice surface}

Below the accumulation basin there is an icefall about $600 \mathrm{~m}$ high (Fig. 5). Ogives form at the foot of the icefall at about $4100 \mathrm{~m}$ a.s.l. As described above, ogives on the western glacier stream were extended and the glacial terminus was crevassed (Fig. 5).

On the western side of the lower part of the glacier there are areas where the surface debris is fresher than that lying on the eastern side, and vegetation is absent. On the other hand, vegetation like Astragalus membranaceus, the compositae family, poplar and willow are common over the eastern ice stream. This suggests that the western glacial stream is notably more active than the eastern branch.

\section{Deposits}

Till deposited during the glacial advance 50 to 60 years ago was on the inner slope of the lateral moraine, and in circular, hilly and wedge-shaped deposits exposed in the tongue-shaped breach cut in the lake bed during the release of 1988. The primary geomorphological difference between the old and new moraines is in the composition of the vegetation. Pine, fir, cypress, poplar, and willow are dominant on the old moraines, and secondary forest such as poplar and willow on the new ones. The tongue formed by the rapid glacial advance in 1988 was covered with heavy debris. Owing to differential ablation, karst landforms were produced.

Zelunglung and Midui Glaciers both experience extraordinary, sudden advances that are major hazards for people and for transportation corridors. Such advances are likely in the future, in view of the evidence for periodic readvance, and these glaciers therefore need to be monitored.

The periodicity of the advances and the rapid motion implied by available observations suggest surge-behaviour for these glaciers (Meier and Post, 1969). Midui Glacier may be tentatively classified as a surge-type glacier. Zelunglung Glacier shows characteristics possibly indicative of ice avalanche behaviour, where motions are fast enough that inertial forces become significant, as suggested by the engulfment of the village of Zhibei in 1950. On the other hand, the avalanche down the side valley may have been incidental to typical surge motion in the main channel of the glacier which raised the surface sufficiently to allow ice to fall over the lateral moraine and down Zhibei valley to the village. The tongue of ice that advanced down the main valley remained coherent, as in the usual surge motion described by Meier and Post (1969).

The existence of surges in the mountain ranges of Tibet extends the geographical extent in which surge-type behaviour is known.

\section{REFERENCES}

Li, J. 1986. Modern glaciers on Mt Gangrigabu. In Zhu, S., ed. Glaciers in Xizang (Tibet). Beijing, Science Press, 140-148. [In Chinese.]

Meier, M. F. and A.S. Post. 1969. What are glacier surges? Can. F. Earth Sci., 6(4), 807-817.

Post, A.S. 1960. The exceptional advances of the Muldrow, Black Rapids and Susitna Glaciers. F. Geophys. Res., 65(11), 3703-3712.

Ward, F.K. 1926. Exploration in south-eastern Tibet. Geogr. F., 67(2), 97-123.

Ward, F. K. 1934. The Himalaya east of the Tsangpo. Geogr. F., 84(5), 369-397.

Zhang, W. 1985. Some features of the surge glacier in the Mt Namjagbarwa. Mountain Research, 3(3), 234-238. [In Chinese with English abstract.]

Zhang, W. 1987. Preliminary study on modern glacier in Mt Namjagbarwa region. In Lanzhou Institute of Glaciology and Geocryology. Academia Sinica, ed. Proceedings of the Second National Conference on Glaciology of the Geographical Society of China (selection). Lanzhou, the People's Publishing House of Gansu, 111-115. [In Chinese with English abstract.]

The accuracy of references in the text and in this list is the responsibility of the author/s, to whom queries should be addressed. 